\title{
Büyük adenomatöz kolorektal poliplerde human papilloma virüs varlığının araştırılması
}

\author{
Mehmet Ali ERDOĞAN ${ }^{1}$, Ali Ramazan BENLİ²
}

\begin{abstract}
$\ddot{\mathbf{O} z}$
Kolorektal kanser dünya çapında en sık görülen malignitelerden biridir. Genellikle adenomatöz polip zemini üzerinde gelişir. İnsan papilloma virüsü (HPV), anogenital enfeksiyonlara neden olur ve serviks kanseri ile iyi bilinen bir ilişkiye sahiptir. Bununla birlikte, HPV ve kolorektal polip ve kanser arasındaki ilişkiyi araştıran çalışmalarda çelişkili sonuçlar vardır. $\mathrm{Bu}$ nedenle, kanser potansiyeli yüksek olan kolorektal adenomatöz poliplerde HPV varlığını değerlendirdik. Çalışmaya, alt gastrointestinal semptomların taranması veya değerlendirilmesi için total kolonoskopi uygulanan hastadan $\geq 1 \mathrm{~cm}$ boyutundaki polip alınd. Numuneler, real-time PCR kullanılarak 25 genotip için tarand. Real-time PCR kullanılarak DNA izolasyon analizinde hiçbir örnekte HPV DNA saptanmadi. Sonuç: HPV ile adenomatöz kolorektal polipler arasında bir ilişkinin olamadığına inanıyoruz. Bu konuyu açıklığa kavuşturmak için daha fazla çalışmaya ihtiyaç vardir.
\end{abstract}

Anahtar Kelimeler: Human papilloma virüsü, adenomatöz polipler, kolorektal kanser
Yayın Bilgisi

Gönderi Tarihi:17.08.2018

Kabul Tarihi:18.08.2018

Online Yayın Tarihi:30.09.2018

DOI: $10.26453 /$ otjhs. 454432

Sorumlu Yazar

Mehmet Ali ERDOĞAN

\section{Investigation of presence of human papilloma virus in large adenomatous colorectal polyps \\ Mehmet Ali ERDOĞAN ${ }^{1}$, Ali Ramazan BENLİ}

\begin{abstract}
Colorectal cancer is one of the most common malignancies worldwide. It often develops on grounds of adenomatous polyp. Human papilloma virus (HPV) causes anogenital infections and has well-known association with cervix cancer. However, there are conflicting results in the studies investigating relationship between HPV and colorectal polyps and cancer. Thus, we evaluated presence of HPV in colorectal adenomatous polyps with high potential for cancer. The study included polyps $\geq 1 \mathrm{~cm}$ in size from patient who underwent total colonoscopy for screening or evaluation of lower gastrointestinal symptoms. Samples were screened for 25 genotypes by using real-time PCR. No HPV DNA was detected in any of samples in DNA isolation assay by using real-time PCR. We believe that there is no association of colorectal adenomatous polyps with HPV. Further studies are needed to clarify this issue.
\end{abstract}

Article Info

Keywords: Human papilloma virus, adenomatous polyps, colorectal cancer

Corresponding Author

Mehmet Ali ERDOĞAN

${ }^{\overline{1}}$ Department of Gastroenterology, Inonu University Medical Faculty, Malatya, Turkey

${ }^{2}$ Department of Family Medicine, Karabuk University Faculty of Medicine, Karabuk,Turkey

\section{INTRODUCTION}

Colorectal cancer (CRC) is one of the most common malignancies worldwide, resulting from adenomatous polyps in most cases. Adenomatous polyps are benign epithelial tumors with malignant potential and $95 \%$ of colon cancers arise from these polyps. However, adenomas have malignant transformation potential by $5 \% .^{1}$ Colorectal carcinoma risk is increased in adenomatous villous/tubulovillous polyps larger than $1 \mathrm{~cm} .{ }^{2}$ Human papilloma virus (HPV) infects basal epithelial cells such as skin and mucosa. High-risk genotypes of HPV lead 
mainly to cervix cancer as well as other mucosal tumors. ${ }^{3}$ Given the fact that HPV is associated to anogenital or oropharyngeal cancers, studies have been conducted to investigate relationship between HPV and CRC; however, such a relationship is unclear. Besides studies showing relationship between HPV and CRCs, there are also studies proposing vice versa. ${ }^{4,5}$

In this study, we investigated whether or not HPV plays role in formation and malignant transformation of adenomatous colorectal polyps that are involved in the development of colorectal cancers.

\section{MATERIAL AND METHOD}

\section{Patients and Study Sample}

This study was conducted at Endoscopy Unite of Karabuk Teaching Hospital of Karabuk University. The study included patients (aged $\geq 18$ years) who underwent total colonoscopy for evaluation of lower gastrointestinal symptoms or screening. The patients unwilling to participate and those with additional pathology in colon (Crohn's disease, ulcerative colitis etc.) were excluded. All colonoscopy evaluations were performed by an experienced gastroenterologist and polypectomy was performed to all polyps detected during colonoscopy. Polyps with a size of $\geq 1 \mathrm{~cm}$ had been accepted as large polyps. ${ }^{6}$ Of polyps removed, samples taken from those $\geq 1 \mathrm{~cm}$ in size were placed in plates specially designed for HPV screening and stored at $-80^{\circ} \mathrm{C}$. The polyps removed were placed into formaldehyde solution for pathological evaluation. The polyps reported to be adenomatous were included.

This study was approved by local ethical committe Karabuk University, decision number: $2016 / 4$

Written informed consent was obtained from the patient who participated in this study

\section{HPV assay method}

Firstly, DNA extraction was performed by using magnetic bead-based Magrev Viral DNA/RNA Extraction kit in order to prepare samples for real-time PCR.

Then to detect extraction success and formation of PCR reaction conditions, internal control DNA was added into the samples. The DNAs of extracted samples were amplified using Montania 4896 Real-Time PCR instrument with Bosphore HPV Detection Kit v4 (SYBRGreen method) and amplicon presence was confirmed by melt curve analysis. The kit that has been used, is the same brand as the system and is valid and it is used for clinical use as IVD-CE mark. The included internal control DNA was studied separately and isolation success and absence of PCR inhibition in samples was confirmed.

Method validation was provided with the use of negative control (no detection) by observing the increased internal control in the samples and determining the amplification and amplicon presence in positive control. Reliability of 
results was ensured by confirming absence of amplicon in all samples via melt curve analysis. Samples were screened for 25 genotypes of $\operatorname{HPV}(6,11,16,18,26,31,33,35,40,43,44$, $53,56,58,62,66,67,68,69,72,73,74,81,83$, 89 ) by using real-time PCR analysis.

\section{Statistical analysis}

SPSS version 17.0 program was used for statistical evaluation. Descriptive data were expressed as mean \pm standard deviation, median (min-max) and percent (n) where appropriate. Chi-square test was used to compare nonparametric data.

\section{RESULTS}

Overall, 49 patients were included in the study. Of these, 32 (\%65.3) were men and 17 (34.7\%) were women. Mean age was $60.46 \pm 11.92$ years. Polypectomy sites are shown in (Table 1).

Histopathological examination of samples revealed severe dysplasia in $65.3 \%(n=32)$ and mild dysplasia in $34.3 \%(n=17)$. Carcinomatous foci were detected in one sample with severe dysplasia.

No significant relationship was detected between involvement site and severity of dysplasia $(\mathrm{p}=0.42)$.

In HPV screening, no HPV was detected in obtained samples. No Target DNA could be detected in DNA extracts by real-time PCR analysis (Figure 1a,1b). These results were confirmed by formed amplicons using melt curve analysis (Figure 2a,2b). The included internal control DNA was studied separately and isolation success and no PCR inhibition was observed in samples (Figure 3a,3b).

\section{DISCUSSION}

In this study, the presence of HPV in adenomatous colorectal polyps $>1 \mathrm{~cm}$ in size could not be detected. In the studies conducted so far, HPV has been linked to many cancers, mainly anogenital cancers. HPV strains such as HPV 16, 18-31 and 45, considered to be oncogenic, were detected in cervix cancers and anal cancers. ${ }^{7,8}$ Apart from these, HPV DNA was isolated in tissue samples from head-neck cancers $^{9}$, esophagus cancers 10 and oral cancers. ${ }^{11}$ The malignant transformation potential of the colonic polyps depends on size, histological features and phase of epithelial atypia. Adenomatous polyps are generally smaller in size with lower malignant transformation potential while villous polyps are larger with higher potential for transformation. The villous adenomas exhibit more severe atypia than adenomatous polyps. Most adenomas are not transformed into cancers while small percentage of these adenomas show malignant transformation and it is believed that colorectal cancer arises over this ground. ${ }^{12}$ Colon cancers develop from adenomas as a result of multi-stage process involving DCC, Kras and p53 gene mutation where several environmental factors play role. ${ }^{13}$ 
Many studies have been published investigating the relationship between HPV and colorectal polyp and cancers. In a study by Mlynarczyk et al., HPV 16 and 18 were found to be more prevalent in colon cancers (67\%) and adenomas $(56 \%)$ than normal colon mucosa (28\%). Authors suggested that HPV 16 and 18 may have roles in the pathogenesis of colon cancer. ${ }^{14}$ In a study involving 106 patients, HPV DNA was detected in 41 tumor tissue specimens and 33 normal tissue samples. ${ }^{15}$

Although there are studies suggesting a relationship between colorectal cancer and adenomatous polyps, studies suggesting the absence of such relationship are also present. In a study on 279 patients, Michele et al. investigated 37 types of HPV in all samples but no HPV was detected. In that study, studies showing that colon cancer and polyps are associated with HPV have been suggested to be related to contamination. ${ }^{5}$ In a study by Yavuzer et al., no HPV DNA was detected in 106 cases of colorectal cancer and 62 cases of adenoma. ${ }^{16}$ In another study on 167 adenomatous polyps including 87 hyperplastic colorectal polyps, no relationship was detected between HPV and polyps. ${ }^{17}$ In a study on 132 patients, Gazzez et al. detected no relationship between HPV colonization and CRP/CRC development. ${ }^{3}$ In a study by Shoreyer et al., it was found that HPV was associated with anorectal squamous cell carcinomas but not adenocarcinomas. ${ }^{18}$ The role of HPV is well-known in cervix cancer. In cervix, HPV is detected in squamocolumnar (SC) junction and ectocervix which is lined by non-keratinizing, stratified squamous epithelium. Furthermore, HPV leads to malign transformation of squamous cells in SC junction. The fact that HPV is detected in areas lined by squamous cells in polyps and cancer but not in columnar epithelium of colon suggests that HPV can survive in squamous epithelium but not in columnar epithelium.

In this study, we investigated adenomatous polyps $>1 \mathrm{~cm}$ in size with high malignant transformation potential. Study samples included polyps with mild and severe dysplasia and carcinomatous foci were detected in a polyp with severe dysplasia. In 5 cases, synchronous carcinoma was detected in a region other than polyp. No HPV was detected in samples taken from these cases. In conclusion, it is seen that HPV has no role in development of adenomatous polyps and their malignant transformation. However, further studies are needed in this field.

\section{ACKNOWLEDGMENT}

This research was supported by Karabuk University, Karabuk/ Turkey

\section{REFERENCES}

1. Brenner $\mathrm{H}$, Altenhofen $\mathrm{L}$, Katalinic $\mathrm{A}$, Lansdorp-Vogelaar I, Hoffmeister M. 
Sojourn time of preclinical colorectal cancer by sex and age: estimates from the German national screening colonoscopy database. Am J Epidemiol. 2011; 174(10): 1140-1146.

2. Atkin WS, Morson BC, Cuzick J. Long-term risk of colorectal cancer after excision of rectosigmoid adenomas. N Engl J Med. 1992; 326(10): 658-662.

3. Gazzaz F, Mosli MH, Jawa H, Sibiany A. Detection of human papillomavirus infection by molecular tests and its relation to colonic polyps and colorectal cancer. Saudi Med J. 2016;37(3):256.

4. Chen TH, Huang CC, Yeh KT, et al. Human papilloma virus $16 \mathrm{E} 6$ oncoprotein associated with p53 inactivation in colorectal cancer. World J Gastroenterol. 2012; 18(30): 4051.

5. Gornick MC, Castellsague X, Sanchez G, et al. Human papillomavirus is not associated with colorectal cancer in a large international study. Cancer Causes Control. 2010; 21(5): 737-743.

6. Hixson LJ, Fennerty MB, Sampliner RE, Garewal HS. Prospective blinded trial of the colonoscopic miss-rate of large colorectal polyps. Gastrointest Endosc. 1991;37(2):125127.

7. Burd EM. Human papillomavirus and cervical cancer. Clin Microbiol Rev. 2003; 16(1): 1-17.

8. D'Ambrogio A, Yearly S, Sahli R, et al. Human papilloma virus type and recurrence rate after surgical clearance of anal condylomata acuminata. Sex Transm Dis. 2009;36(9):536-540.

9. Jelihovschi I, Bidescu AC, Tucaliuc SE, Iancu LS. Detection of human papilloma virus in head and neck squamous cell carcinomas: a literature review. Rev Med Chir a Soc Med si Nat Iasi. 2014; 119(2): 502-509.

10. Mohiuddin MK, Chava S, Upendrum P, et al. Role of human papilloma virus infection and altered methylation of specific genes in esophageal cancer. Asian Pac J Cancer Prev. 2013;14(7):4187-4193.

11. Ritchie JM, Smith EM, Summersgill KF, et al. Human papillomavirus infection as a prognostic factor in carcinomas of the oral cavity and oropharynx. Int $\mathbf{J}$ Cancer. 2003;104(3): 336-344.

12. Muto T, Bussey HJR, Morson BC. The evolution of cancer of the colon and rectum. Cancer. 1975;36(6):2251-2270.

13. Cappell MS. From colonic polyps to colon cancer: pathophysiology, clinical presentation, screening and colonoscopic therapy. Minerva Gastroenterol Dietol. 2007; 53(4): 351-373.

14. Młynarczyk B, Malejczyk M, Muszyński J, Majewski S. The occurrence of human papillomavirus--HPV in the biopsies from colon polyps and cancer. Med Dosw mikrobiol. 2009;61(2):191-196. 
15. Erol D, Bulut Y, Yüce H, Ozercan IH. 17. Burnett-Hartman AN, Newcomb PA, Investigation of the presence of human Mandelson M, et al. No evidence for human papillomavirus DNA in various papillomavirus in the etiology of colorectal gastrointestinal carcinoma samples. polyps. Cancer Epidemiol Biomarkers Prev Mikrobiyol Bul. 2009; 43(2):259-268. 2011; 20:2288-2297.

16. Yavuzer D, Karadayi N, Salepci T, Baloglu 18. Shroyer KR, Kim JG, Manos MM, Greer CE, H, Dabak R, Bayramicli OU. Investigation of Pearlman NW, Franklin WA. Papillomavirus human papillomavirus DNA in colorectal found in anorectal squamous carcinoma, not carcinomas and adenomas. Med Oncol. 2011;28(1):127-132. in colon adenocarcinoma. Arch Surg. 1992 127(6):741-744. 
Table 1. Polypectomy sites of patients participating in study

\begin{tabular}{lcc}
\hline & Percent $(\boldsymbol{\%})$ & $\mathbf{N}$ \\
\hline Rectum & 28.6 & 14 \\
Sigmoid & 42.9 & 21 \\
Transverse colon & 22.4 & 11 \\
Descending colon & 6.1 & 3 \\
\hline
\end{tabular}


Figure 1a,1b. DNA isolation by PCR technique.

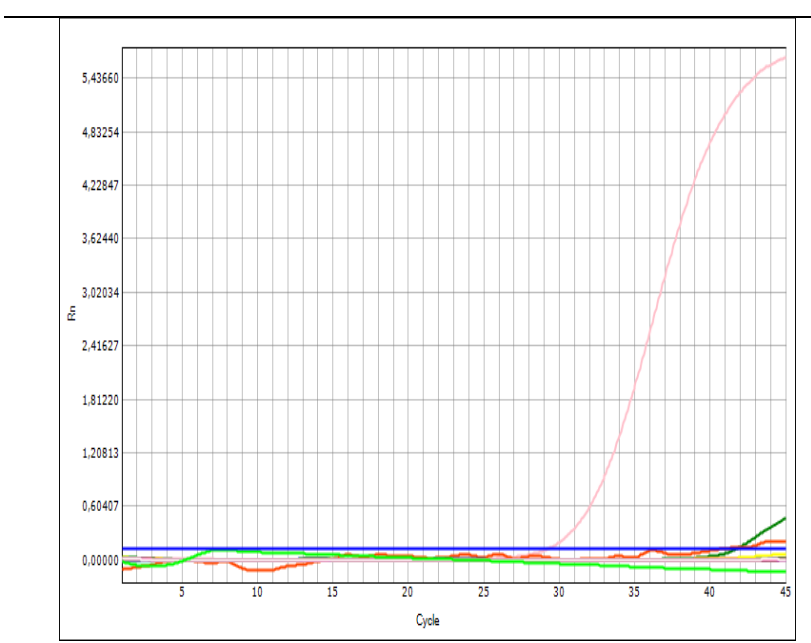

$a$

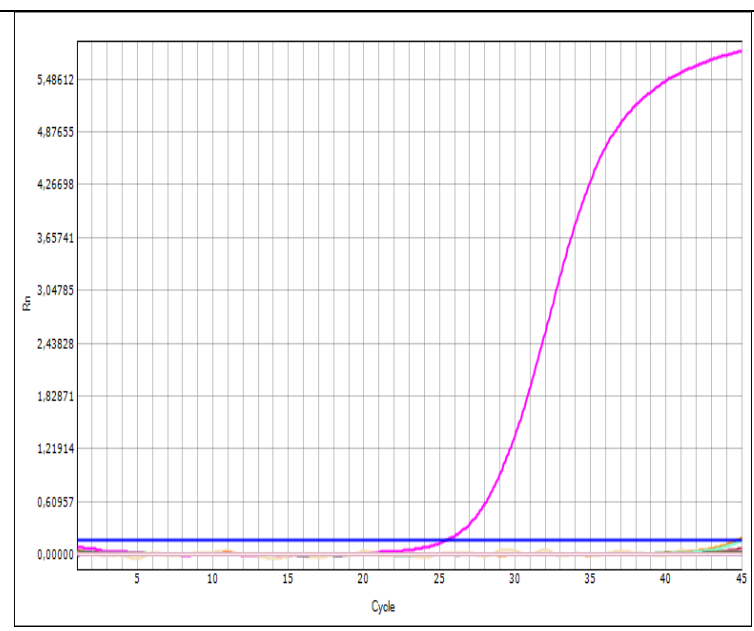

$b$

(a) First 24 patients, (b) other 25 patients 
Figure 2a,2b. Amplicons by melt curve analysis.

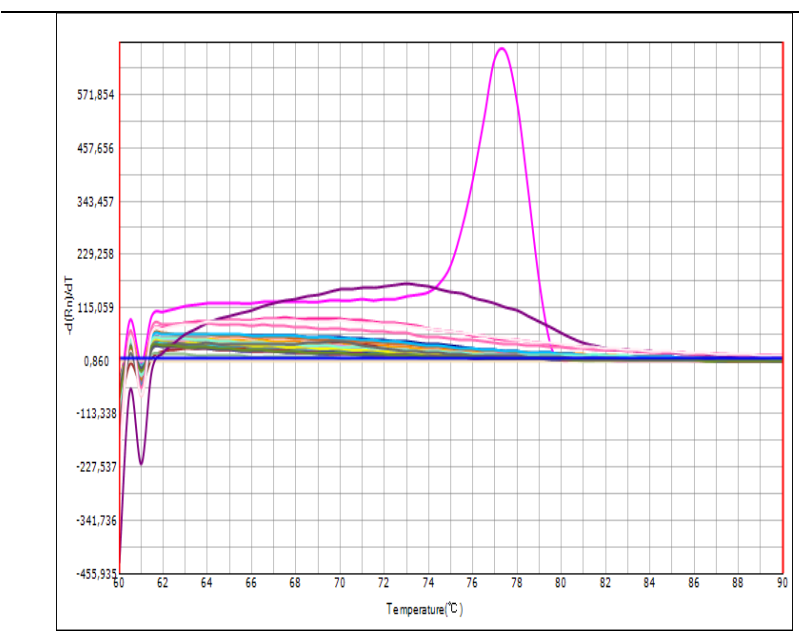

$a$

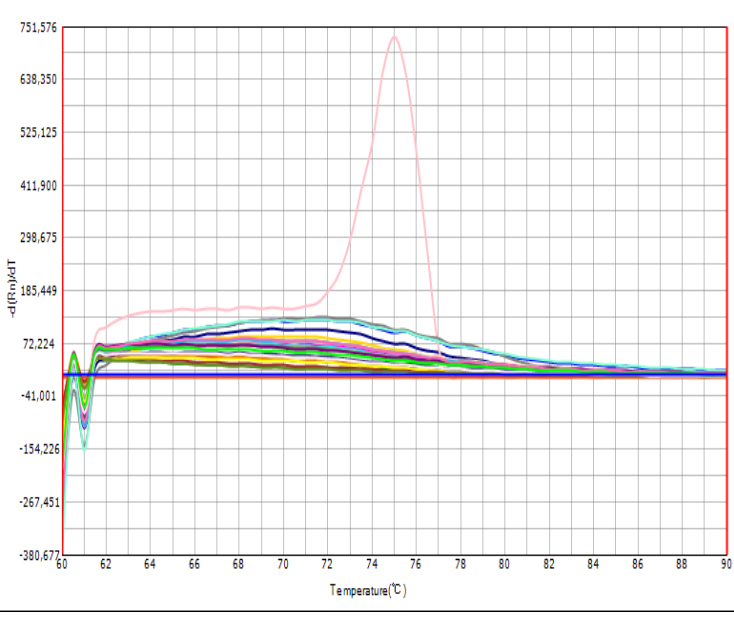

$b$

(a) First 24 patients, (b) other 25 patients 
Figure 3a,3b. Confirmation of analysis by increase in internal control.

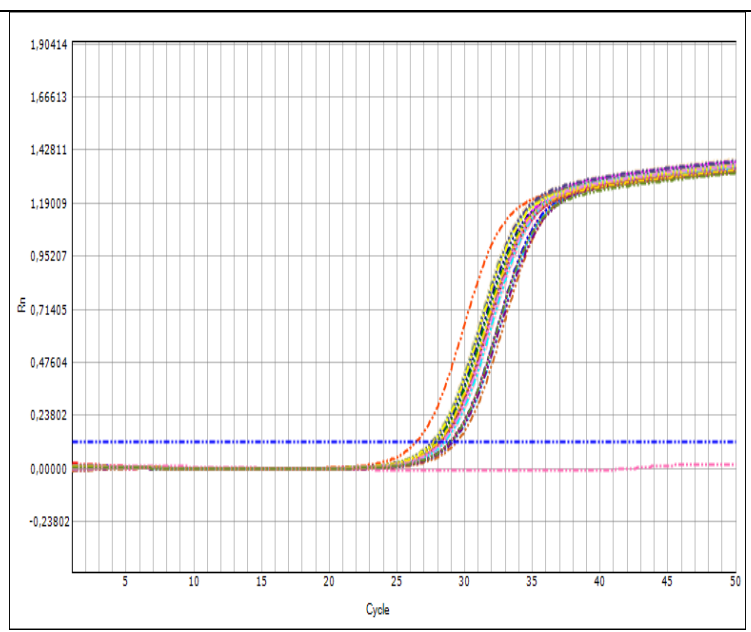

$a$

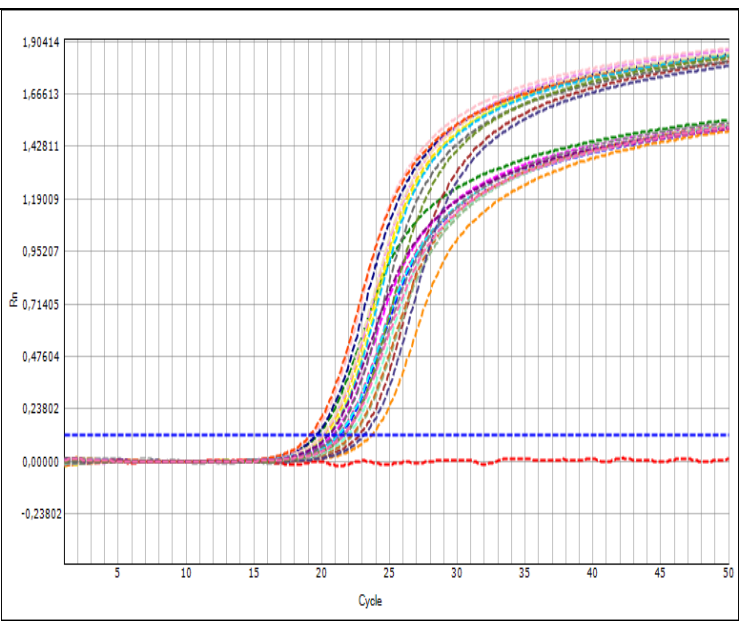

$b$

(a) First 24 patients, (b) other 25 patients 